\title{
In the spotlight
}

Summarize yourself in the form of a title of a paper in Nature.

Geneticist eavesdrops on bacterial conversations and learns to translate multiple chemical languages.

What was your first experiment as a child? I tried to make a candle-propelled steamboat based on a magazine article for kids. It was a total flop — sank like a rock, which partly explains why I did not end up in physics or engineering.

What makes a good scientific mentor?

Patience, a good sense of humour, and always encouraging the student to believe that he or she will figure it out.

What single scientific paper or talk changed your careerpath?

A talk by Michael Silverman about how to use luminescent bacteria as reporters for cell-cell communication. I heard him talk and asked him that day if I could be his postdoc.

What book has been most influential in your scientific career?

Lehninger's Principles of Biochemistry. There was a time when I virtually had it memorized.

What gives you the most job satisfaction now? What are your major frustrations?

Satisfaction: when students or postdocs tell me about some wonderful, creative experiment or result that they came up with on their own. Frustration: trying to get grants to fund the work.

What's your favourite conference destination, and why?

Rome. Great history, sites, museums, food and climate.

What was the worst/most memorable comment you ever received from a referee?

"Genetic experiments mean nothing."

What book is currently on your bedside table? Alessandro Baricco's Ocean Sea.

What musicheads the playlist in your car or lab? Kate Rusby's Hourglass.

Assuming the dead can be raised and/or time travel exists, who from the world outsidescience would you most like to have dinner with?

Virginia Woolf. Her book A Room of One's Own had a tremendous impact on me when I was younger. I think she would have a lot to say, especially about being true to one's self, finding one's passion, and carving out a space and place for oneself.
Under what conditions do you have your greatest and most inspired ideas?

Standing in a hot shower with the water pouring over me.

Where and when would you most like to have lived or worked?

I'm content as is.

You are on a plane behind two students obviously going to the same conference, who start to talk about your work. What do you do?

Listen in of course. That's what I do for my work anyway. Bacteria ... people ... it's all the same to me.

What one thing would you rescue from your burning laboratory?

After all the people, our bacterial strain list.

What's the best piece of advice you've ever received?

"Bonnie, the people who need to know, know."

What do you most dislike about having research published?

It takes us years to think up screens, generate mutants, and identify what the genes do and how the components interact. Once we publish, we have to give the strains out to everyone who asks.

What's the most interesting thing in yourfridge? Eleven different kinds of mustard.

Why is physics so hard?

Because physicists have a pact with each other to speak in gibberish. The sole point is to keep biologists from learning how easy physics and maths really are. That's my theory anyway, or it could be that biologists are bad at disciplines that involve adhering to rules and expressing oneself in mathematical terms.

The Internet is the bane of scientists' lives because...

...e-mail is so distracting.

What do you do to relax?

Singing and acting lessons, aerobics class, hiking, bike riding, reading and cooking.

What would you have become, if not a scientist? I would love to be an actress in the theatre.

What previously under-recognized sportorpastime should be included in the Olympic Games? Ballroom dancing.

What single discovery, invention or innovation would most improve your life?

A self-cleaning house and self-cooking meals.

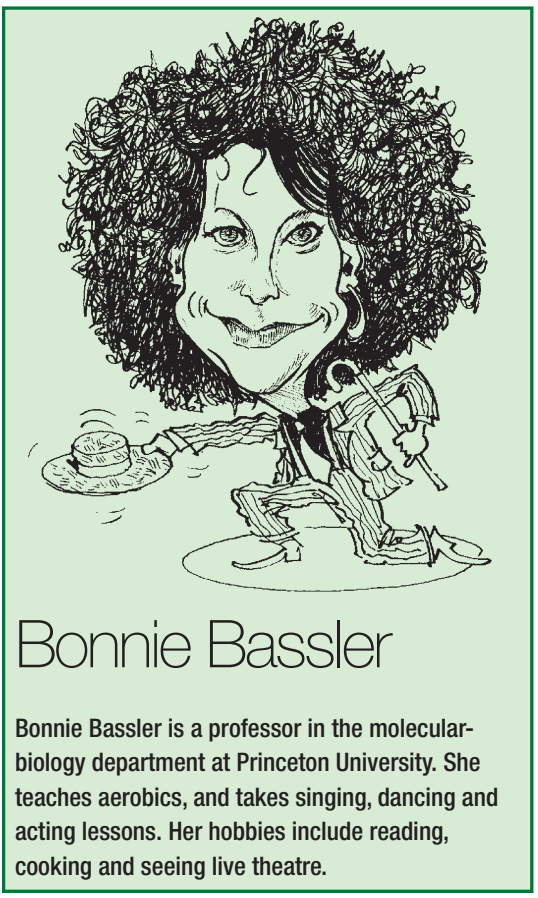

What's the one thing about science that you wish the public understood better?

That we are not nerds, but artists. That what we do and what we are is exciting, creative and fun.

Do you have a burning ambition to do or learn something of no practical or immediate value? I would be a contortionist in the Cirque du Soleil.

Which field in science (apart from your own) deserves more funding, and why?

The interface of theoretical physics/mathematics and biology.

What music would you have played at your funeral?

Bach's unaccompanied cello suites (Prelude from Suite Number 1 in G Major, BWV 1007).

How would you like to be remembered?

That I was creative, passionate and authentic; that I always loved science and was always willing to be surprised; that I was a clear communicator; that my group always did first-rate science, and that I always gave the credit for the work to the students and postdocs who did it.

What's your motto?

You make your luck.

You are fond of theatre: which actor would best portray you in a film?

Lily Tomlin.

What's just around the corner?

Even more surprises. Proudly waiting, with bittersweet anticipation, to be put out of business by my students. 